\title{
RHODESIAN \\ RADIOCARBON MEASUREMENTS II
}

\author{
J. G. SHEPPARD and E. R. SWART \\ Department of Chemistry, University College of Rhodesia \\ Salisbury, Rhodesia
}

The following is a list of dates which has been obtained since the compilation of List I in December 1963. Owing to an irreparable leak in our original counter, it became necessary to replace it with a new counter of similar design using the same shield as before. The new counter has been operated both at $500 \mathrm{~mm} \mathrm{Hg}$ pressure, where it has a background of 1.7 counts $/ \mathrm{min}$ and an NBS oxalic count of 11.4 counts $/ \mathrm{min}$, and at $1000 \mathrm{rmm} \mathrm{Hg}$ pressure, where it has a background of 2.5 counts $/ \mathrm{min}$ and an NBS oxalic count of 22 counts/min.

We have continued to use acetylene as our counting gas and the method we use for estimating our error is essentially the same as that outlined by Callow, Baker, and Hassall (1965), apart from the fact that we do not carry out any $\delta \mathrm{C}^{13}$ measurements.

Our pre-treatment for organic samples remains the same as previously described. In the case of shells we have followed the procedure of Dyck, Fyles, and Blake (1965) and given our samples between $30 \%$ and $40 \%$ pre-leach with hydrochloric acid.

We would like to record our thanks to Miss E. A. Heggarty who has carried out the work of preparing and counting the samples.

\section{SAMPLE DESCRIPTIONS}

I. ARChAFologic SAMPLES

\section{A. East Africa}

\section{SR-16. Cherangani Hill, Kenya}

$1210 \pm 90$

A.D. 740

Peat sample found 175 to $185 \mathrm{~cm}$ below surface $\left( \pm 1^{\circ} \mathrm{N}\right.$ Lat, $35^{\circ}$ $28^{\prime}$ E Long). Coll. and subm. by Prof. van Zinderen Bakker, Palynological Research, Univ. of the Orange Free State, Bloemfontein, South Africa (van Zinderen Bakker, 1962).

\section{SR-64. Magosi Site 2, Uganda}

$6080 \pm 130$

Charcoal found $1 \mathrm{ft} 10 \mathrm{in}$. deep in grey stony earth $\left(34^{\circ} 31^{\prime} \mathrm{N}\right.$ Lat, $2^{\circ} 56^{\prime}$ E Long). This date and several others still to be determined may provide date for Wilton culture in Uganda. Coll. and subm. by M. Posnansky, Assistant Director of British Inst. of History and Archaeol. in East Africa, P. O. Box 3913, Kampala, Uganda. 
Charred wood from third layer of Iron-age site at Ntereso $\left(9^{\circ} 07^{\prime}\right.$ $\mathrm{N}$ Lat, $1^{\circ} 13^{\prime} \mathrm{W}$ Long). Coll. and subm. by O. Davies, Dept. of Archaeol., Univ. of Ghana, Legon, Ghana.

\section{SR-61. Ntereso, Ghana}

Charcoal from top filling (Layer 1) of same site. Date probably marks introduction of iron in Ghana which may be taken as ca. 1000 B.c.

\section{SR-18. Fernando Poo}

$1270 \pm 100$

Charcoal ( $3^{\circ} 25^{\prime} \mathrm{N}$ Lat, $8^{\circ} 45^{\prime} \mathrm{E}$ Long). Coll. and subm. by A. Martin, C.M.F., Inst. Claretiano de Africanistas, Apdo 10, Santa Isabel, Fernando Poo, West Africa. Comment: sample is thought to correspond to early Neolithic of Fernando Poo.

\section{Southern Africa}

\section{SR-22. Ingombe Ilede, Lusitu}

$1120=200$

Charcoal found at depth of 2 to $3 \mathrm{ft}$, to help date Zambian Iron Age $\left(16^{\circ} 10^{\prime} \mathrm{S}\right.$ Lat, $28^{\circ} 47^{\prime} \mathrm{E}$ Long). Gold burials from site were dated ca. A.D. 850. Coll. and subm. by Dr. B. Fagan, Keeper of Prehistory, RhodesLivingstone Mus., P. O. Box 124, Livingstone, Zambia.

SR-23. Ingombe Ilede, Lusitu

$1160 \div 100$ A.D. 800

Charcoal from the $3 \mathrm{ft}$ level. Comment: cross-checked with Q-720 dated at A.D. $985 \pm 100$ (Cambridge VI) .

SR-21. Ingombe Ilede, Lusitu

$1580 \pm 100$

Charcoal from the $3 \mathrm{ft}$ to $10 \mathrm{in}$. level.

\section{SR-31. Isamu Ipati mound, Kalomo}

$910 \pm 90$

Charcoal from 18 in. depth. This Kalomo culture dates Zambian Iron age. Coll. and subm. by Dr. B. Fagan.

SR-30. Isamu Ipati mound, Kalomo

Charcoal from $42 \mathrm{in.} \mathrm{depth.}$

\section{SR-19. Isamu Ipati mound, Kalomo}

Charcoal from bedrock.

$$
930 \pm 100
$$

$$
1300 \pm 90
$$

A.D. 650 
SR-20. Isamu Ipati mound, Kalomo

Charcoal from $3 \mathrm{ft}$ level.
$1852 \pm 100$ A.D. 100

A.D. 1080

SR-74. Karundu mound, Kalomo

Charcoal from Karundu mound, which is $2.9 \mathrm{mi}$ SE of Kalomo. Karundu mound dates further confirm Zambian Iron age culture $\left(17^{\circ}\right.$ 03' S Lat, $26^{\circ} 30^{\prime}$ E Long). Coll. and subm. by Dr. B. Fagan.

SR-66. Karundu mound, Kalomo Charcoal.

SR-41. Karundu mound, Kalomo Charcoal.

SR-65. Karundu mound, Kalomo

Charcoal.

SR-57. Behrens site, Kalomo

Charcoal from old Tonga settlement. It is hoped to use clate to place arrival of Tonga people in Southern Province of Northern Rhodesia. Coll. and subm. by Dr. B. Fagan.

\section{SR-42. Kangila mound, Mazabuka}

Bone $\left(15^{\circ} 55^{\prime} \mathrm{S}\right.$ Lat, $27^{\circ} 50^{\prime} \mathrm{E}$ Long). Date was obtained on inorganic content of bone, and may therefore be somewhat younger than true age. Date is first type-site of Kangila ware of northern part of Southern Province plateau. Coll. and subm. by Dr. B. Fagan.

\section{SR-45. Kamusongolo Kopje Cave, Kasempa $\quad 13,300 \pm 250$ North Western Province, Zambia} A.D. 900

A.D. 790

A.D. 300

$110 \pm 90$

$510 \pm 100$

$1050 \pm 100$

Charcoal ( $13^{\circ} 27^{\prime}$ S. Lat, $25^{\circ} 51^{\prime}$ E Long). The absolute dating and time span of the Later Stone age occupation of $\mathrm{N}$ of the Kafue and $\mathrm{W}$ of eastern Lungar has hitherto been untouched. Coll. and subm. by S. Daniels, Natl. Monuments Comm., P. O. Box 124, Livingstone, Zambia.

\section{SR-62. Dambwa, Livingstone}

$1330 \pm 110$

Charcoal ( $17^{\circ} 49^{\prime} \mathrm{S}$ Lat, $25^{\circ} 51^{\prime} \mathrm{E}$ Long), found on a living site with evidence of iron smelting; dates Early Iron age occupation in Southern Province of Zambia. Coll. and subm. by S. Daniels.

\section{SR-47. Zimbabwe}

$570 \pm 90$

Charcoal from hut floor in middle of Great Enclosure (21 $3^{\prime} \mathrm{S}$ Lat, $31^{\circ} 31^{\prime}$ E Long). Coll. by Dr. E. Swart; subm. by R. Summers, Director, 
Natl. Mus., P. O. Box 240, Bulawayo, Rhodesia. Comment: date confirms M-915 (Michigan VI).

\section{SR-58. Aboyne Mine, Fort Rixon}

A.D. 1300

$650 \pm 110$

Charcoal from a "firesetting" in a pre-European gold mine $\left(20^{\circ} 5^{\prime}\right.$ S Lat, $29^{\circ} 21^{\prime} \mathrm{E}$ Long). Mine collapsed killing at least four miners whose bones were mixed with charcoal. Coll. and subm. by R. Summers.

\section{SR-53. Aboyne Mine, Fort Rixon}

Charcoal from same site as SR-58 and should be exactly contemporary with SR-58. Coll. and subm. by R. Summers.

SR-43. Mabveni

$1770 \pm 120$

\section{A.D. 180}

Charcoal from Gomanye Hill in Chibi Tribal Trust Area $\left(20^{\circ} 22^{\prime}\right.$ $\mathrm{S}$ Lat, $30^{\circ} 28^{\prime} \mathrm{E}$ Long), found in ashy midden in association with Gokomere pottery. Coll. by K. Robinson; subm. by R. Summers.

\section{SR-44. Woolandale Farm, Bulawayo}

$$
640 \pm 90
$$

Charcoal from midden heap belonging to Leopard's Kopje industry, Phase 3. Coll. by K. Robinson; subm. by R. Summers.

\section{SR-68. Taba-ka-Mambo}

$1080 \pm 100$

Charcoal from 36 to 42 in. level. Coll. and subm. by K. Robinson, Hist. Monuments Comm., Natl. Mus., P. O. Box 240, Bulawayo, Rhodesia.

\section{SR-55. Leopard's Kopje, Khami Waterworks,} Rhodesia

$1250 \pm 110$

Charcoal from a domestic fire belonging to Leopard's Kopje industry, Phase 2. Coll. by K. Robinson; subm. by C. Cooke, Hist. Monuments Comm., P. O. Box 3248, Bulawayo, Rhodesia.

\section{SR-69. Tshangula cave, Matopo Hills}

$112 \pm 90$

Charcoal from Layer 1 which also contained Wilton artifacts, Bambata ware, and Leopard's Kopje ware (21 $38^{\prime} \mathrm{S}$ Lat, $28^{\circ} 36^{\prime} \mathrm{E}$ Long) . Coll. and subm. by C. Cooke.

\section{SR-75. Tshangula cave, Matopo Hills}

$2150 \pm 100$

Charcoal from bottom half of Wilton level. Coll. and subm. by C. Cooke. Comment: although samples 69 and 75 appeared to come from undisturbed strata, anomaly of the dates compelled further attention to the stratigraphical record. It is possible that these strata could have been disturbed by rain wash from the back of the cave and consequently the 
two dates must be accepted with great reserve. Further sampling is in progress.

\section{SR-73. Masuma River, Wankie National Park}

$1140 \pm 90$

Charcoal from a sealed position in eroded midden containing pottery similar to Gokomere type (18 $36^{\prime} \mathrm{S}$ Lat, $26^{\circ} 20^{\prime} \mathrm{E}$ Long). Coll. by K. Robinson; subm. by C. Cooke.

\section{SR-70. Harleigh Farm, Rusape}

$$
610 \pm 90
$$

Charcoal from a Zimbabwe culture settlement $\left(18^{\circ} 32^{\prime} \mathrm{S}\right.$ Lat, $32^{\circ}$ 05' E Long) . Coll. and subm. by P. Robins, Univ. Coll. of Rhodesia, P. Bag $167 \mathrm{H}$, Salisbury, Rhodesia. Comment: see SR I for more dates from this site.

\section{SR-71. Harleigh Farm, Rusape}

$440 \pm 90$

Charcoal. Coll. and subm. by P. Robins.

\section{SR-63. Striped Giraffe shelter, South West Africa}

Striped Giraffe shelter is in Karibib District of South West Africa. Charcoal found in an ash hearth 12 to 15 in. below surface. Date gives a basal date for local South West African variant of Later Stone age (Erongo culture), which shows acculturation with Wilton. Coll. and subm. by H. MacCalman, Archacol., State Mus., P. O. Box 1203, Windhoek, South West Africa.

\section{SR-46. Numas Entrance Shelter, South West} Africa

\section{A.D. 1080}

$870 \pm 100$

Numas Entrance shelter is in Numas Ravine of the Brandenberg mountains $\left(14^{\circ} 28^{\prime} \mathrm{E}\right.$ Lat, $21^{\circ} 10^{\prime} \mathrm{S}$ Long). Charcoal sample, associated with Wilton Later Stone age material in ash layer 2 to 6 in. below the surface, from an undisturbed deposit (Rudner, 1957). Coll. and subm. by H. MacCalman.

\section{SR-51. Thakadu Copper Prospect}

$410 \pm 100$

Charcoal from Thakadu Copper Prospect, $60 \mathrm{mi} \mathrm{W}$ of Francistown $\left(21^{\circ} 6^{\prime} \mathrm{S}\right.$ Lat, $27^{\circ} 32^{\prime} \mathrm{E}$ Long), Bechuanaland Protectorate. Sample came from a stope $18 \mathrm{ft}$ below surface in an ancient copper working and gives indication of time when copper was first worked in this area. Coll. by G. Woodward, Rhodesian Selection Trust; subm. by Prof. G. Bond, Geology Dept., Univ. of Rhodesia, P. Bag, 167H, Salisbury, Rhodesia.

II. GEOLOGIC SAMPLES

\section{SR-67. Shell mound of Revez Duarte}

$$
28,540 \pm 490
$$

Oyster shell found on bank of Umbeluzi River, Portuguese East Africa $\left(26^{\circ} 2^{\prime} 3^{\prime \prime} \mathrm{S}\right.$ Lat, $32^{\circ} 24^{\prime} 15^{\prime \prime} \mathrm{E}$ Long), some $61 / 2 \mathrm{~m}$ above present 
sealevel. Sample taken from 4th layer (numbering from bottom) of a profile containing 9 distinct layers. Mound is partially of human origin and sample layer itself contains paleoliths from Middle Stone age. Date marks occurrence of the Gamblian-Makalian inter-pluvial in Mozambique (Barrados, 1955). Coll. and subm. by L. Barradas, Inst. de Investigacao Cientifica de Mozambique, Caixa Postal 1780, Lourenco Marques, Mozambique.

\section{SR-72. Kassimatis Quarry}

$33,720 \pm 700$

Oyster shell found on bank of Matola River, Portuguese East Africa $\left(25^{\circ} 58^{\prime} 22^{\prime \prime} \mathrm{S}\right.$ Lat, $32^{\circ} 26^{\prime} 10^{\prime \prime} \mathrm{E}$ Long), some $21 / 2 \mathrm{~m}$ above present sealevel on a raised beach. Sample taken from 3rd layer of a profile containing 8 distinct layers. Date marks occurrence of the Gamblian-Makalian inter-pluvial transgression. Coll. and subm. by L. Barradas.

\section{SR-29. Forno da cal, Maputo River}

Shell sample (Balanus sp.) from bank of Maputo River, Portuguese East Africa (26 25' 25" E Lat, $32^{\circ} 39^{\prime} 45^{\prime \prime} \mathrm{S}$ Long), some $41 / 2 \mathrm{~m}$ above present sealevel. Sample taken from 3rd layer of a profile containing 6 layers. Date marks later stages of Gamblian-Makalian transgression in Mozambique. Coll. and subm. by L. Barradas.

\section{SR-27. Chidenguela}

$4090 \pm 150$

Fossil mollusca occurring in a sandstone wall running parallel to the littoral at the beginning of the Makalian regression (Borges, 1939). Coll. and subm. by L. Barradas.

\section{SR-40. Situmpa Forest Station, Machili, Zambia A.D. 240}

$$
1710 \pm 100
$$

Charcoal sample ( $16^{\circ} 50^{\prime} \mathrm{S}$ Lat, $25^{\circ} 07^{\prime} \mathrm{E}$ Long), from a forest pit in the Kalahari sand; depth 42 in. Coll. and subm. by B. Fagan. Comment: sample has been dated in order to check C-662 (4078 \pm 300 ; Libby, 1952), which was much older than expected.

Corrections to Southern Rhodesia I, Radiocarbon, vol. 6, p. 31-36.

SR-11. Pomongwe cave, Matopo Hill. '1st Intermediate Stone age' should read '2nd Intermediate Stone age.'

SR-24. Situmpa Forest Station. 'Depth 42 in.' should read 'depth 48 in.'

Date lists:

$$
\text { REFERENCES }
$$

$\begin{array}{ll}\text { Cambridge VI } & \text { Godwin and Willis, 1964 } \\ \text { Chicago III } & \text { Libby, 1952 } \\ \text { GSC IV } & \text { Dyck, Fyles and Blake, 1965 } \\ \text { Michigan VI } & \text { Crane and Griffin, 1961 } \\ \text { NPL III } & \text { Callow, Baker and Hassall, 1965 } \\ \text { SR I } & \text { Robins and Swart, 1964 }\end{array}$


Barradas, L., 1955, Complexos geologico-arcqueologicos do Quaternario no sal de Mozambique: Boletin No. 90 da Sociedade de Estudos de Mozambique-Lourenco Marques.

Borges, A., 1939, Depositos Fercianos e post-plicoenos do distrito de Inhambane: Boletin No. 3 dos Scricos de Industria, Geologis e Minas-Lourenco Marques.

Callow, W. J., Baker, M. J., and Hassall, Geraldine I., 1965, National Physical Laboratory radiocarbon measurements III: Radiocarbon, v. 7, p. 156-161.

Cranc, H. R., and Griffin, J. B., 1961, University of Michigan radiocarbon dates VI: Radiocarbon, v. 3, p. 105-125.

Dyck, W., Fyles, J. G., and Blake, W., 1965, Geological Survey of Canada radiocarbon dates IV: Radiocarbon, v. 7 , p. 24-46.

Godwin, H., and Willis, E. H., 1964, Cambridge University natural radiocarbon measurements VI: Radiocarbon, v. 6, p. 116-137.

Libbs, II. F., 1952, Chicago radiocarbon dates III: Science, v. 116, p. 673-681.

Robins, P. A., and Swart, E. R., 1964, Southern Rhodesian radiocarbon measurements I: Radiocarbon, v. 6, p. 31-36.

Rudner, J., 1957, The Brandenberg and its archaeological remains: Jour. of S.W.A. sci. Soc., v. 12 